\title{
Socio-economic stability, intra party democracy and the power transition in the Communist Party of China
}

\section{Introduction}

Power transition plays an important role in shaping the political landscape of a state. In any policy-making structure, leaders and politicians strive for a proper formula for the power transition and personal succession. While in democratic systems the major role is played by public opinion, in other political systems different factors function as a substitute for direct elections.

In fact until the Cultural Revolution, two major periods marking changes in the power structure within the Communist Party of China may be distinguished. The first period can be dated from the beginning of establishing the party in 1921 up to the Zunyi Conference in 1935, when the Party was shaken by power struggles at the national level, which brought about frequent changes of leaders and of the party apparatus. After the Long March up till the end of the Great Leap Forward, the power structure remained relatively stable. After the experiences of the Great Leap Forward and during the Cultural Revolution, the struggle for the future succession became a "the zero sum game." In the late 1970s and mid 1980s, the power transition problem still remained unresolved and it entailed a variety of challenging tasks. In fact, the understanding of the Tiananmen mistake and embracing the world's economy turned into a more peaceful leadership change. From this perspective the debates over China's future leadership are important due to a variety of reasons. On the one hand, the top leader shapes the political, economic and social landscape of the country. On the other hand, he should be able to respond to societal sentiments and public opinion as well as have a significant say on the basic ideological questions.

The article mainly aims to discuss the critical factors of power transition within the Chinese Communist Party framework since the last peaceful transition between Jiang Zemin and Hu Jintao. The major objective of the paper is to show when and how the changes in leadership came about. Moreover, the issues to 
answer have been: how have the historical experiences such as the Tiananmen crisis, the further opening-up in 1992 or economic performance affected the political transition in Mainland China? What kind of internal determinants have played a crucial role in a venerable or peaceful succession? The major issue to discuss is how economic performance might challenge the issue of peaceful transition at the central level.

In terms of the factional divisions adumbrated earlier, booms favor the political interests of radical reformers, ceteris paribus, whereas busts serve the interests of the central planning authorities and ministers. They see these busts as an opportunity to retrench the private and collective sectors and redress the economic balance in favor of the planned state sector (Dittmer, 2003, p. 421).

In order to understand the process of power transition, the author has observed and compared selected cases. The main differences between the three cases of power transition inside the Communist Party of China are presented and discussed in the article, namely: Hu Yaobang-Jiang Zemin, Jiang Zemin$\mathrm{Hu}$ Jintao and the future leadership - Xi Jinping. On the one hand, through the comparative approach the author seeks historical generalizations and general conclusions based on a concrete, although rather simplified, knowledge about specific cases (Burnham, Gilland Lutz, Grand, Layton-Henry, 2008, p. 71-74). On the other, the adoption of the comparative approach will enable the author to point out a model of economic development, the success or failure of which brings about the internal discussion on the future development of China. In this respect, all the problems, questions and doubts, which have been raised, stimulate uncontrolled factionalism. This has been the major reason for unstable successions. The breakthrough involves factions as well as factional groups and their struggle over power. In order to win, one of the two or three groups have to take the political initiative through political campaigns e.g. for the whole nation to learn from the army (quan guo xue jiefang jun) or to persist with progress (baohu xianjing xun). Taking the initiative leads to the redistribution of power and consequently to the removal of one or more factions. Finally, the winners purge the losers and dominate the party apparatus with the result of internal turbulence and the loss of international influence. Having taken the path of reforms, Chinese authorities needed to create a peaceful environment at the national level to pull the country out of the crisis after the Cultural Revolution.

The term 'political culture' has been narrowed down to mean guanxi - an informal political inter-relationship, which plays a pivotal role in shaping the future of power transition inside the Chinese Communist Party. For the sake of this analysis, factionalism will be understood as a state of affairs 'characterized by two symbolic phenomena: informal groups linked by personal ties competing for dominance within their parent organization, and informal personal influences prevailing over the formal due process in decision making.' (Jin Hong, 2002, p. 42). 
According to Goldstein (1991), political outcomes are essentially determined by the structure of the political system. This system attempts to institutionalize the possible leadership transition. In a one-party system, the personal consensus and the institutionalized succession have been based on the negative experiences from history, which has been a principle factor behind the increasing level of stability in the central echelons. Legitimacy itself is a recognition of the right to govern. Scholars have defined legitimacy as the acceptance of the organization by its environment and have considered it as a vital factor for organizational survival and success.

On the other hand, China's traditional way of legitimizing power the original justification - was not accepted by the general public, but rather derived from 'mandate of Heaven' (tian ming), 'rule by virtue' (renzhi), 'popular consent' (minben) and 'legality' (hefa). In the Confucian paradigm of the Great Harmony (datong), there was a system of moral harmony in which the emperor was supposed to be the gentlest man in the world (junzi) (Wang Fuchun 1999, p. 49-51). In the context of minben, which is the most important aspect related to the problem of the concept's performance, the Chinese understanding of the relations between the governor and the governed suggested that rulers had to seek popular approval, not by way of expressed public opinion, but rather through winning their hearts and minds. As Mencius noted: Here is the way to win the empire: win the people and you win the empire. Here is the way to win the people: win their hearts and you win the people. Here is the way to win their hearts: give them and share with them what they like, and do not do to them what they do not like. The people turn to a humane ruler as water flows downward to beasts take to wilderness. In fact Guo Baogang (2008) summarizes the Chinese traditional ideas of political legitimacy as follows: a ruler, who has the mandate of Heaven, possesses the quality of virtue, shows respect to his subjects, follows the rules of the ancestors, and tries to win the hearts and minds of the people, will be considered a just and legitimate one.

The second kind of legitimacy is an eudemonic legitimacy or utilitarian justification that derives from the capacity of the rulers to meet the people's needs. Chinese traditional thoughts used the following concepts to account for the utilitarian vision of power: benefiting people (limin) and equality (junfu). This kind of legitimacy refers to successful economic performance and effective provision of economic benefits to individuals in the society (Feng Chen, p. 421-425).

The source of legitimacy for these developmental stages resided in a cultural construction of politics combined with the modern symbol of legitimacy - economic growth (Compton, 2000). This leads to an assumption that legitimacy might be recognized as a result of tradition, historical experiences, economic development and social changes. As Dittmer pointed out (2003), both success and 
failure of economic reforms provoke the masses to protest. In this context, radical reformers may have the upper hand during a boom, pushing their policies of loose money, economic reforms and vigorous market expansion. It is conceivable that the present "chill", in which the most prolonged retrenchment yet is compounded by military suppression, purge of the reform leadership, and an economic slowdown, may finally bring inflation to heel and permit reforms to resume on a more stable economic footing. (see table 1).

Table 1. Level of mass acceptance for economic performance and the type of leadership

\begin{tabular}{|c|c|c|c|}
\hline \multicolumn{2}{|c|}{ Boom } & Bust & \\
\hline \multirow{2}{*}{$\begin{array}{c}\text { Mass } \\
\text { activities }\end{array}$} & High & Tolerance & $\begin{array}{c}\text { Purge } \\
\text { reformers }\end{array}$ \\
\cline { 2 - 5 } & Low & Purge conservative & Chill \\
\hline
\end{tabular}

Source: L. Dittmer, Patterns of Elite Strife and Succession in Chinese Politics, "The China Quarterly”, 1990, vol. 123, p. 425.

Since China took the path of opening up and introducing reforms, the political elites should be flexible and adaptable to the people's sentiments. This, among others, creates a political atmosphere at the central level of leadership and can exert a positive or negative effect on the way of transition.

\section{Economy growth and social stability}

The two types of power transitions described above were deeply rooted in the economic conditions of China. While in the late 1980s China was plunged into the economic crisis, in the late 1990s and at the beginning of $21^{\text {st }}$ Century China enjoyed economic growth that stimulated social stability. According to the research carried out between 1953 and 1978, the state revenue as a percentage of national income averaged 34.2 percent, and in 1988 it reached only $19.3 \%$. The situation of financial decentralization allowed local governments to gain benefits of increased autonomy and control over the allocation of funds. The situation in the late 1980sled to broadened discussions held by economists and policy makers over what they referred to as "reforms" and "adjustment" of the structure of the economy. One of the reasons for the debates was that from 1985 the Chinese economy witnessed a persistent inflation and economic disruption (Wang Hui, 2003, p. 50). Moreover, on the eve of the Tiananmen crackdown, with food prices and wages climbing and the system flushing with cash, the overall inflation skyrocketed, averaging nearly 19 percent both in 1988 and 1989. The transition to a market economy affects the inflation mechanism.(Kojima, Nakamura, Ohyma, 2005, p. 3-4). A prepared succession of Hu Yaobang was 
challenged by the economic crisis. He was purged from the party apparatus in January 1987 due to the support coming from the society. Zhao Ziyang, who took the post of secretary general, was in favor of liberal reforms. His own concepts of future democratic liberalization and free market economy as a measure to counter the growing inflation and slowing economy were cross-examined. These two issues constitute a central theme of the discussion, which has been outlined above in the first part of the paper. In general the conservatives, with Chen Yun as their leader, took their chance and put forward arguments against the liberal group. The Hu Yaobang and Zhao Ziyang case clearly showed that the slowing economy together with the collapse of the socialist regimes in Central Europe and Russia have been in favor of conservatives.

On the other hand, during the Jiang Zemi-Hu Jintao transition in 2002 China's economy had no inflation. However, it did experience deflation twice: from 1998 to 1999, and again from the end of 2001 to the end of2002. More over at that time, China enjoyed economical growth and foreign trade surplus. (compare table no 2 and graph no 1). This, as compared with the late 1980s, should be considered as one of the major factors in preventing the central authorities from passing the power smoothly. Furthermore, unlike the late 1980s and during the collapse of communism, on the eve of the $16^{\text {th }}$ Party Congress China joined the World Trade Organization.

Table 2. Inflation in China 1980-2002

\begin{tabular}{|c|c|c|c|}
\hline 1980 & 5.988 & 1992 & 6.4 \\
\hline 1981 & 2.383 & 1993 & 14.7 \\
\hline 1982 & 1.928 & 1994 & 24.1 \\
\hline 1983 & 1.5 & 1995 & 17.1 \\
\hline 1984 & 2.828 & 1996 & 8.3 \\
\hline 1985 & 9.3 & 1997 & 2.8 \\
\hline 1986 & 6.5 & 1998 & -0.8 \\
\hline 1987 & 7.3 & 1999 & -1.4 \\
\hline 1988 & 18.8 & 2000 & 0.4 \\
\hline 1989 & 18 & 2001 & 0.725 \\
\hline 1990 & 3.1 & 2002 & -0.767 \\
\hline 1991 & 3.4 & 2003 & 1.167 \\
\hline
\end{tabular}

Souce: Inflation in China http://www.economywatcom/world_economy/china/inflation.html [accessed March 14 March 2010]. 


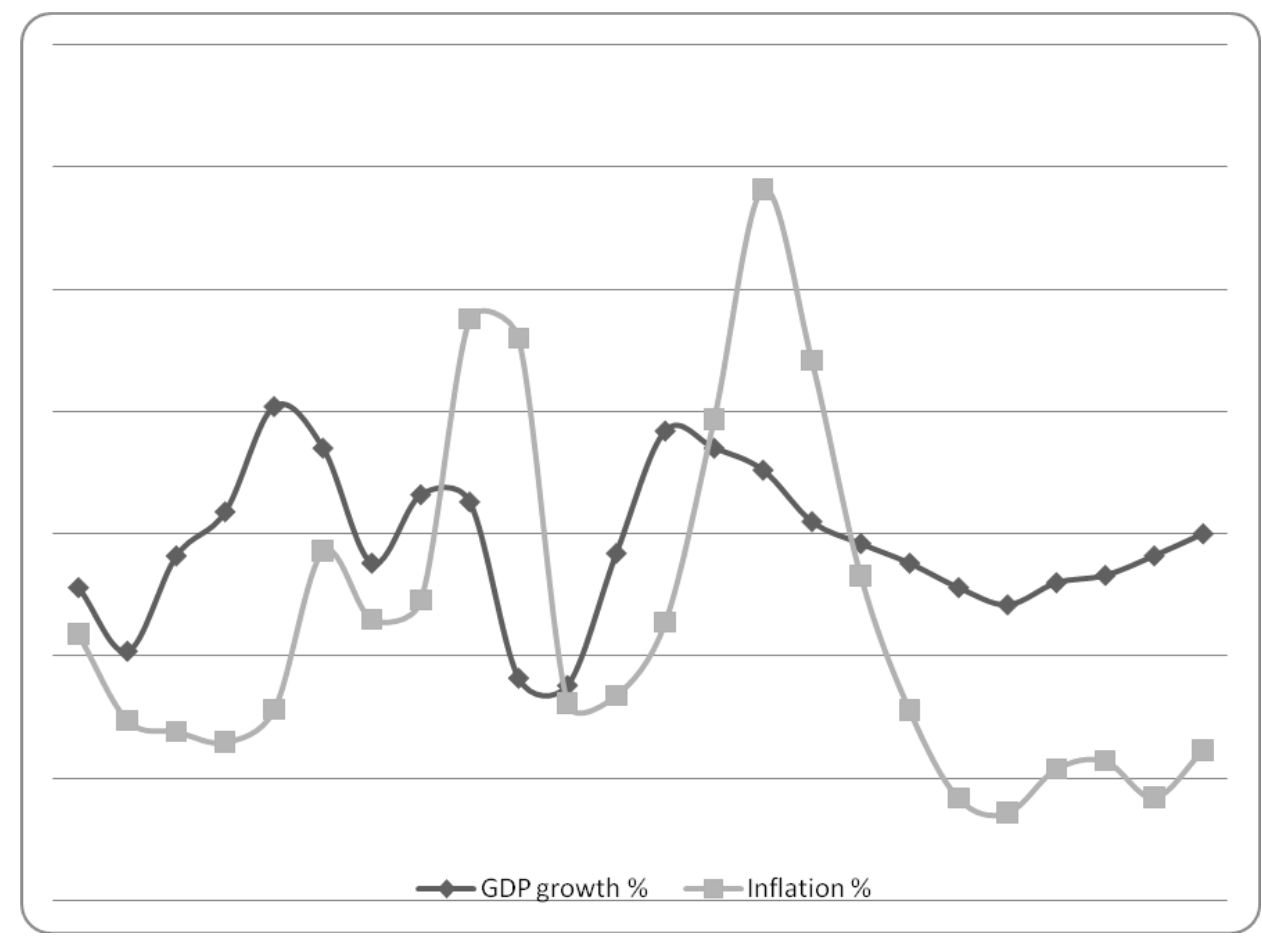

Graph 1. GDP and inflation ratio between 1980 and 2003

Source: based on economic indicators published online http:/www.economywatch.com/world economy/china/inflation.html(accessed on 13 March, 2010)

According to the latest survey published by the Chinese Academy of Social Science (CASS),sustainable economic growth plays an important role insocial and political stability. In 2002 Chinese officials ranked economic stability as a first-rank sign of social stability. Moreover, the importance of leadership stability has been growing since 2002. This brings us to the conclusion that social instability would cause a peaceful or turbulent power transition.In the survey, as pointed out by the respondents, political stability was regarded as more importantin the year of power transition than earlier on. In 2001 , only $12.7 \%$ pointed to political stability as the most important factor, while in $2002-23 \%$. This tendency clearly shows that local elites were aware of the Jiang Zemin and $\mathrm{Hu}$ Jintao transition during the $16^{\text {th }}$ Party Congress. (see table no 3 ).

Table 3. The most important sign of social stability (as a first choice)

\begin{tabular}{|c|c|c|c|c|c|c|}
\hline & 2001 & 2002 & 2003 & 2004 & 2005 & 2007 \\
\hline $\begin{array}{c}\text { Economic growth } \\
\text { stability }\end{array}$ & $\mathbf{6 4 , 7}$ & $\mathbf{5 2 , 6}$ & $\mathbf{5 6}$ & $\mathbf{4 9 , 5}$ & $\mathbf{4 9 , 7}$ & $\mathbf{5 3 , 2}$ \\
\hline Emotional stability & 13,7 & 15 & 14,7 & 26,2 & 18,9 & 21,4 \\
\hline
\end{tabular}


Table 3. (cont.)

\begin{tabular}{|c|c|c|c|c|c|c|}
\hline Leadership stability & $\mathbf{1}$ & $\mathbf{0 , 8}$ & $\mathbf{1 , 7}$ & $\mathbf{1 , 9}$ & $\mathbf{2 , 1}$ & $\mathbf{2 , 6}$ \\
\hline Price stability & 1 & 0,8 & - & 0,9 & 0,7 & 1,3 \\
\hline Security stability & 3,9 & 2,3 & 4,3 & 4,7 & 8,4 & 2,6 \\
\hline Political stability & $\mathbf{1 2 , 7}$ & $\mathbf{2 3 , 3}$ & $\mathbf{1 6 , 4}$ & $\mathbf{1 5}$ & $\mathbf{1 1 , 9}$ & $\mathbf{1 3 , 6}$ \\
\hline $\begin{array}{c}\text { Standard of living } \\
\text { stability }\end{array}$ & - & 4,5 & 3,4 & 0,9 & 4,9 & 3,9 \\
\hline Employment stability & 2,9 & 0,8 & 3,4 & 0,9 & 3,5 & 1,3 \\
\hline
\end{tabular}

Source: Xie Zhiqiang, Pan Jia, Dangzheng lingdao ganbu dui 2007-2008 nian Zhongguo shehui xingshi de jiben kanfa (Basic Options of the Leading Cadres on China's Social Situation of 2007-2008), in: Zhongguo shehui xingshi fenxi yu yuce, Shehui Kexue Wenxuan Chubanshe, Beijing 2008, p. 147.

As the CASS surveys indicate, the central leadership should be aware of the economic and social stability. According to the statistics, the food price inflation generally runs well above overall CPI - general inflation, like in the period from 2007 to the end of 2008, when food prices rose well above 7 percent every month and reached a peak of 23 percent in February 2008. This is not a problem that can be solved easily for us since food supply and demand are barely changeable.

As some economists state, China's inflation has already begun. By 2012, the year when Xi Jinping should take power over the party-state apparatus, the inflation will have become a serious social problem. This most likely would be caused by the real estate bubble burst. As the inflation is global, the Federal Reserve will have to raise interest rates to $5 \%$ or more, which in turn, might lead to hot money flowing away from China. The second point is that China will have to raise interest rates so as to cope with inflation, and to prevent excessive loss of funds. (Xie Guozhong 2010).

This might increase social unrest in China. The local Party authorities enjoy extensive control over the media, judiciary system, local legislatures and village committees. As a result, Chinese citizens are using organized protest activities more and more extensively to circumvent the control of local officials over formal political and legal institutions in order to prompt the intervention of higher-level officials in resolving citizen grievances.

\section{Intra-party democracy and rule of law}

The second factor that might challenge the above-presented model is the ongoing internal discussion on the future of the leadership. As for the central government, the debates are limited, but the discussions seem to be important with regard to the local level. The election examples coming from down to up might provoke 
serious challenges for the future of Chinese leadership transitions. Starting with the village committees that enjoy elections coming up to the provincial level, the new leadership might be selected. As China's Prime Minister Wen Jiabao argued, institutional checks and balances, constitutionalism, freedom of the media, civil liberties and political choice expressed through elections are not proprietary elements of Western democracies, but are the essential and universal components of any democracy (Wen Jiabao, 2010).

It was one of the major issues during the Fourth Plenary Session of the 17th CPC Central Committee in September 2009 to ensure that the CCP intra-Party democracy is "the lifeblood of the Party". The directives explicitly called for political reforms in five major areas: 1. more competitive inner-Party elections to choose CCP officials; 2 . a more consensus-based decision-making process called "decision by votes" (piaojuezhi); 3. more restrictive rules to regulate the tenure, transfer, and regional allocation of high-ranking leaders; 4. a multi-dimensional supervision system to restrain official corruption and other forms of power abuses; 5. a new emphasis on the transparency of Party affairs. As mentioned by Su Jinsheng (2008), the concept of kexue fazhan guan should change the model based on a patron-client relationship. Sustainable economic growth needs political achievements (zhengji), and the party must create a positive atmosphere inside China. The selection should be based on transparent and publicly known (gongrenxing) indicators. The correct selection (zhengque xuanze) should be independent/carried out independently from the Organization Department, but based on the candidate's achievements and talent instead.Guandong in 2008 is a good example of this, as the government implemented the four big signs (sida bakuai) of efficiency: economy, society, individuals and ecology. Such an application of the clearcut set of criteria should serve to avoid the subjective assessment of the cadres and avert the accusation of using cadres for particular purposes (xuan ren yong ren) (Su Jinsheng, 2008). Zhang Shulin (2009) presents a high level democracy (gaoceng minzhu), which should be the ideal type of political solution. However, if not properly controlled at the local level, it might lead to turbulence and instability. An interesting type of democratic solutions discussed by Chinese scholars and applied in reality is cha'e xuanji - based on the rule of more nominees than the number of seats. As the Party secretary in Nanjing and Jiangsu between 2001 and 2007, Li Yuanchao, the director of the powerful CCP Organization Department and a Politburo member, routinely implemented intra-Party elections of top local leaders. This political experiment took place much earlier than in other cities and provinces. This constitutes a challenge to the mentality of those leaders who were "obsessed with stability" (taiping guan) and who refused to try new political experiments (Cheng Li, 2007).

On the other hand, Shenzhen aspires to the rank of the first special political zone in China. In May 2008 the city elected the new Party secretary of the Futian District and the head of the Shenzhen Municipal Office of High Technological 
Development, with two candidates vying for each post. It should be noted that for liberal scholars, intra-Party democracy is only the means, not the end, to fulfilling China's democratic aspirations. In their view, it would be a grave mistake to assume that all China needs is the intra-Party democracy, instead of a truer people's democracy (renmin minzhu) or social democracy (shehui minzhu), both of which would require the grassroots for general democratic elections. (Chen Li, p.2-3).

More to the point, the cha'e хиапju system was applied in voting for the Central Committee seats. In the 2007 Party congress the delegates voted to elect 204 full members from the total number of 221 candidates on the ballot (8.3 percent more). As for the alternate members, the delegates voted to elect 167 alternates from the total number of 183 candidates on the ballot $(9.6$ percent more). It has been widely noted that the individuals eliminated in these elections were usually those leaders who came from the privileged families of high-ranking officials, known in China as princelings (taizidang). In the 1997 Party congress for example, several princelings, including Chen Yuan, Wang Jun, and Bo Xilai, were among the 5 percent of the candidates rejected despite (or perhaps because of) the fact that their fathers had served as vice premiers (Dittmer, 2000). This also explains why leaders from the princeling backgrounds are usually less enthusiastic about the intra-Party democracy than their nonprinceling colleagues. In fact, as a son of Xi Zhongxin, Xi Jinping is recognized as a member of the taizidang group. This might, as in the past, lead to the conclusion that the majority of party members fail to vote for this group. What is more, this might challenge the commonly held belief that the Committee would allow to spread the cha'e xuanju type of election to the Politburo and Standing Committee itself (Cheng Li, 2007). As proposed by Zhang Shulin (2009), competitive elections should be applied gradually to the highest level, and the proportion should be between $5 \%$ and $15 \%$.

In the knowledge-based economy (zhishihua de jingji), people are not only satisfied with their material life but also have ambitions to shape the political scene. This would suggest that the social need should be preserved by the rule of law. Tang Daiwang and Tang Chaoyang (2006) argue that the general change of the role of the government would also change the role of the citizens (gongmin) from duty (yiwu benwei) to the right-oriented citizens (quanli benwei). This might also challenge the presented model. The Communist Party of China will rather find its legitimacy by stabilization via participation. The scientific development view (kexue fazhan guan) shows a different perception of the citizens. According to the Chinese scholars, while applying the yi ren wei ben policy, the government should abandon the traditional concept of the feudal period guan wei gui, min wei $j i$ (government is the most important, people less). The government should be the servant of people and should find a proper formula to establish correct "relations with the masses". More to the point, between 1998 and 2002 the concept of xiao zhengfu, da shehui (small government, big society) changed the quantity 
of government on all administrative levelsby $20 \%$. The amount of personnel in the State Council was reduced by $47 \%$ and provincial administrative personnel by $50 \%$. (L. Dittmerr, p. 909 ).

The public opinion is more and more demanding. For the Chinese leadership, efficiency is one of the most important issues. It has been one of the most desirable effects expected by the public opinion. In this context, the leadership selection might be appropriated by the central authorities to the current development of society. The efficiency, in the context of the $10^{\text {th }}$ National People's Congress (NPC), fails to be the banner of the ruling party. As Prime Minister Wen Jiabao points out, "the central government must imply a better fiscal policy as soon as possible in order to develop a standardized platform for local financing measures and guard against potential financial risks" (Wen Jiabao, 2010). The central government has been aware of the coming financial crisis. The Central Bank and the China Banking Regulatory Commission surveys found out that the local platforms had borrowed over 5 trillion yuan by the end of December 2009, with nearly 90 percent of stimulus projects tied to bank loans. The surveys also said these loans amounted to 240 percent of local government revenues. To limit the "bad loans", the central government approved the new projects on a strict control of the local government fiscal policy and banks credit facilities (Shen Minggao, 2009).

The second aspect of intra-Party democracy is how to elect the party secretary and president of the state. The concept of dang-zheng fenkai was presented by Zhao Ziyang in the late 1980s. In 2003, in his book Political Reform and Governmental Innovation, Xie Qingkui published a few surveys on the separation of party and government from 1988 and 1990. According to the results of the pool, $78.5 \%$ - the majority of party-government officials - supported the idea of separation, while 19\% were rather skeptical (Xie Qingkui, 2003, p. 71-77). These debates on the formulation of law and regulations strengthened the legislative bodies in China, like the. National People's Congress. In the context of the future leadership, the NPC should be considered as a very useful tool in the intra party struggle over the balance of power.

Xi Jinping, considered as a future leader of China, was not officially appointed by the paramount leader as his successor. In comparison with Hu Jintao, who was named by Deng Xiaoping, Xi Jinping posses a relatively weak position. More importantly, as the earlier practice shows, Xi's elevation to the Central Military Commission $(\mathrm{CMC})$ was blocked and not put forward in the $4^{\text {th }}$ Plenum agenda. Given that Hu himself got into the CMC in 1999 - three years before the then-vice president was made the party chief - quite a few Central Committee members wanted Xi to be accorded the same treatment in September 2009. (Willy Lam, 2009). In this context, an interesting observation has been made by a Chicagobased scholar Victor Shih. In September 2009, along with the decision of putting $\mathrm{Xi}$ Jinping on the sidelines, the Standing Committee of the National People's 
Congress enforced a new draft of Mobilization Law. Firstly, the mobilization must be approved by the NPC Standing Committee. Secondly, both the State Council and the CMC will implement this order from the NPC. This should be considered as an example of a power dilution through institutional changes.

\section{Conclusion}

The logic of the presented peaceful transition model has been deeply rooted in the historical experience of the Communist Party of China. But in fact the peaceful transition, at least, would face two basic challenges. On the one hand, the growing inflation and social instability, while on the other hand the intra-party democracy and role of law nexus.

As Lowell Dittmer states, the central leadership answered to the public sentiments more than one could expect. In fact, the ongoing economic transformation affects social stability. Therefore, the social stability or instability based on economic performance plays a crucial role in the central leadership selection. In the late 1980s hyperinflation and economic instability led to a heated discussion and the purging of the liberal reformers. In late 1990s the leadership with Hu Jintao and Wen Jiabao took power under the social stability and equality banner. This was due to the social problems in China and it played an important role in shaping the nature of the leadership.

The same situation might occur, as some economists believe, in 2012 - the year of $18^{\text {th }}$ Party Congress. In fact, in the recent years in China, the nominal GDP has been $4.5 \%$, while the short-term interest rate is zero, which has been a precedent of some kind. This is due to the fact that the growth of interest should be closely linked to the GDP growth, such as when South Korea's economic growth reached double-digits, when the level of interest is also a doubledigit growth. Xie Guozhong has predicted that the bubble would finally burst in 2012 and would consequently provoke the second economic crisis. The major issue then will be how China should react to the crisis (Victor Shih, 2010 and Xie Guozhong, 2010).

Economic and social instability of any kind provokes discussion on whether and how to react to the crisis. What is more important, the crisis itself plays an important role in strengthening the tendency for grouping and factionalism inside the Communist Party of China. As the new draft of the Mobilization Law has clearly indicated, factionalism still plays an important role in China's political landscape. Wu Bangguo, more affiliated to the former leader Jiang Zemin, has supported Xi Jinping by providing him with a countermeasure to not being a member of the Central Military Committee.

As all the above-mentioned factors indicate, the transition of power has been still exposed to the danger of instability at the central level. The turbulence at 
the central level has been caused by two major factors: socio-economic instability and factionalism. If the central leadership hopes to enjoy the peaceful transition at this level of development, it should make it a law; otherwise the informal groups and intra-party struggle over power will lead to China's instability.

\section{References}

Bi Jianhai (2003). “The Chinese leadership succession: does it complete or continue?". New Zealand International Review, 28: 2.

Bi Jianhai (2008). "Political Transition in China". New Zealand International Review, 33: 17.

China Leadership Completes Transition as President Hu Assumes Military. URL: <http://www. voanews.com/english/archive/2005-03/2005-03-13-voa6.cfm?CFID=107289217\&CFTOKE $\mathrm{N}=79366672$ \&jsessionid=de303d5224f0c4ca1e6e5e1cab6d4e1b6941 > [accessed January 28, 2009)

Dittmer L. (2003). Chinese Leadership Succession to the Fourth Generation. In Lin Gang and Hu Xiaobo (eds.) China After Jiang. Stanford: Stanford University Press.

Dittmer L. (1990). "Patterns of Elite Strife and Succession in Chinese Politics". The China Quarterly, 14: 425.

Easton D. (1979). A Systems Analysis of Political Life. University of Chicago Press.

Fewsmith J. (1994). Dilemmas of Reform in China: Political Conflict and Economic Debate. Armonk, New York, London: An East Gate Book.

Fewsmith J. (2001). China since Tiananmen: The Politics of Transition. Cambridge: Cambridge University Press.

Fewsmith J. (2004). Promoting the Scientific Development Concept. China Leadership Monitor, 11. URL: <http://media.hoover.org/documents/clm11_jf.pdf $>$ [accessed February 1, 2012].

Fuchun Wang. (2003). Waishi guanli xue gailun (An introduction to the Foreign Affairs Administration). Beijing Daxue Guojiguanxi Xueyuan Xili Jiaocai.

Goldstein A. (1991). From Bandwagon to Balance-Of-Power Politics: Structural Constraints and Politics in China, 1949-1978, Stanford: Stanford University Press.

Guo Baogang, Sustaining Political Legitimacy in the Post-Jiang China: Challenges Ahead, Paper presented at the annual meeting of the American Political Science Association, Philadelphia Marriott Hotel, Philadelphia, PA, Aug 27, 2003. URL: <http://www.allacademic.com/meta/ p63268_index.html $>$ [accessed August 23, 2012].

Harding H. (1987). China's Second Revolution, Reform after Mao. Washington: The Brooking Institution.

Hsiao Pen (1999). Separating the Party from the Government. In: Carol Lee Hamrin, Suisheng Zhao \& A. Barnett Doak (eds.), Decision-Making in Deng's China: Perspectives from Insiders. Armonk, New York, N.Y.: A East Gate Book.

Jie Chen, Peng Deng (1995). China since the Cultural Revolution. From Totalitarism to Authoritarism. London: Prager.

Jing Huang (2000). Factionalism in Chinese Communist Politics. New York: Cambridge University Press.

Li Wenling (2003). Zhongguo zhengfu zhineng chuanbian wenti baogao (China Government Function Change Issue Report). Beijing: Zhongguo Fazhan Chuban She.

Miller Lyman H. (2003). The 10th National People's Congress and China Leadership Transition. China Leadership Monitor, 7: 1-3.

Nathan A. \& Gilley B. (2002). China's New Rulers, The Secret Files. New York: New York Review Books. 
Shambaugh D. (2008). China's Communist Party, Atrophy and Adaptation. Woodrow Wilson Press Centre, Washington, Berkeley, Los Angeles, London: University of California Press.

Tang Xiaoqing (2009). Dang nei minzhu yu Dang de xianjinxing shi hudong gong jin guanxi (The intra-party democracy and party's progress are interactive) URL: $<$ http://theory.people. com.cn/GB/49150/49151/4388817.html> [accessed February 5, 2012].

Tanner M. S. (1999). The Politics of Lawmaking In Post Mao China. Oxford: Clarendon Press.

Willy Wo-Lap Lam (2007). "Chinks in the Armour of the Hu Jintao Administration". China Perspective, 3: 4-11.

Xie Zhiqiang, Pan Jia (2008). Dangzheng lingdao ganbu dui 2007-2008 nian Zhongguo shehui xingshi de jiben kanfa (Basic Options of the Leading Cadres on China's Social Situation of 2007-2008), In: Zhongguo shehui xingshi fenxi yu yuce. Shehui Kexue Wenxuan Chubanshe, Beijing.

Yang D. L. (2003). "Leadership Transition and the Political Economy of Governance". Asian Survey, 43: 27-28. 